\title{
Pradziejowa kolonizacja małych dolin rzecznych środkowej Polski i jej konsekwencje dla rozwoju rzeźby
}

\author{
Prehistoric colonization of small river valleys in Central Poland and its implications \\ for the relief evolution
}

\author{
Juliusz Twardy \\ Katedra Geomorfologii i Paleogeografii, Uniwersytet Łódzki, Łódź, twardy@geo.uni.lodz.pl
}

Zarys treści: Praca skupia się na analizie rozwoju den małych dolin rzecznych i ich stoków, w której równolegle uwzględniono zagadnienia prahistorycznego osadnictwa i gospodarki. Zasięg przestrzenny analizy sprowadza się do terenów środkowej Polski, a cezura czasowa zamyka się w młodszej części prahistorii i obejmuje okres od początków epoki brązu po wczesne średniowiecze. W pracy przeprowadzono (1) charakterystykę rzeźby dolin rzecznych Polski środkowej, (2) krótko omówiono rozmieszczenie osad pradziejowych i (3) określono strefy preferowane przez to osadnictwo w stosunku do form rzeźby terenu. Zwrócono uwagę na synchroniczność procesów agradacji den małych dolin rzecznych i procesów stokowych. Jednoczesny rozwój rzeźby den dolinnych i stoków uporządkowano w cztery krótkie fazy, które trwały przeważnie 200-300 lat. Dwie pierwsze przypadają na młodszą część subboreału (SB-2), faza III i krótki epizod pomiędzy fazą III i IV - na starszą część subatlantyku (SA-1), a najistotniejsza i najdłuższa faza IV wystąpiła na początku środkowego subatlantyku (SA-2). Za główny czynnik sterujący rozwojem rzeźby w pradziejach przyjęto antropopresję; fluktuacje klimatu neoholocenu mogły wzmagać skalę przekształceń rzeźby.

Słowa kluczowe: antropopresja, osady stokowe, osady rzeczne, środkowa Polska

\begin{abstract}
The paper focuses on the analysis of the floors of small river valleys and the slopes. Both the problems of prehistoric settlement and economic activity are taken into account. The spatial coverage of the study covers the area of Central Poland, while the time concerns the period between the Bronze Age beginning and the early Middle Ages. This paper presents (1) a morphological characteristics of the small river valleys of Central Poland, (2) briefly describes the distribution of prehistoric settlements, (3) identifies zones favoured by settlers in relation to landforms. The attention has been drawn to the synchronicity between the aggradation of valley floors and slope processes. Simultaneous development of the river valley floors and the slopes has been arranged in four short-term phases, which usually lasted 200-300 years. The first two phases (I-II) took place during the younger part of Subboreal (SB2), the phase III and a short episode during the phases III and IV - at the older part of Subatlantic (SA-1), the longest phase IV, considered to be the most important, occurred at the beginning of middle Subatlantic (SA-2). The main factor steering the relief development in the prehistoric times is considered anthropopressure. Climatic fluctuation of the Neoholocene could have enhanced the scale of relief transformation.
\end{abstract}

Key words: human impact, slope deposits, alluvial deposits, the Middle Poland

\section{Wstęp}

W ostatnich kilkudziesięciu latach podejmuje się problem związków, jakie zachodziły pomiędzy pradziejowym osadnictwem i gospodarką a rozwojem rzeźby w warunkach środowiska coraz silniej przeobrażanego przez człowieka. Doliny rzeczne wydają się dobrym poligonem badawczym dla badania relacji człowiek-środowisko, al- bowiem były chętnie zasiedlane i niejednokrotnie można w ich rzeźbie oraz osadach odszukać zapis antropopresji (Waga, Kocel 2003, Domańska i in. 2009). Trudności sprawia jednak odróżnianie wpływu czynników naturalnych (np. wahań klimatu w holocenie) od czynników antropogenicznych (Starkel 2006a, b), bardzo często synchronicznie oddziałujących na ewolucję rzeźby dolin rzecznych. Punktem wyjścia do badań związku pradzie- 
jowej kolonizacji dolin rzecznych z rozwojem ich rzeźby są studia różnorodnych materiałów archeologicznych, na podstawie których można odtworzyć historię zasiedlania stref dolinnych, uchwycić specyfikę rozmieszczenia ekumen i określić ich związki z formami rzeźby terenu. Określamy tu, w jaki sposób rzeźba, a często także litologia, determinowała poczynania człowieka. Na dalszym etapie poszukuje się zwykle geomorfologicznych i geologicznych dowodów długotrwałej antropopresji. Ponieważ relacja człowiek-środowisko ma charakter relacji obustronnej, na kolejnych etapach badań odpowiadamy na pytanie o kierunki i skalę transformacji rzeźby w środowisku przekształconym przez człowieka.

\section{Cel pracy, wykorzystane materialy i zakres czasowy analiz}

Praca ma na celu przedyskutowanie związków zachodzących pomiędzy rozwojem małych dolin rzecznych i ich stoków w połączeniu $\mathrm{z}$ omówieniem przebiegu zasiedlenia terenu badań. Wykorzystano w niej liczne materiały autorskie, zawierające litologiczną charakterystykę i oznaczenia wieku różnorodnych osadów stokowych (Twardy 1995, 2000, 2003, 2004, 2005, 2008, 2009, 2011, Twardy i in. 2004 a, b, 2008), zebrane na terenie środkowej Polski (ryc. 1). Z obszernej literatury regionalnej wybrano wyniki badań osadów rzecznych, których autorzy w swych interpretacjach uwzględnili czynniki antropogeniczne, oddziałujące $\mathrm{w}$ małych dolinach rzecznych podczas składania serii osadów powodziowych (Kamiński 1993, 1998, Kamiński, Moszczyński 1996, Kamiński, Miklas 1998, Kamiński, Twardy 1998, Marosik 2002, Forysiak 2005). Materiały archeologiczne stanowiły zarówno wyniki badań powierzchniowych, prowadzonych w ramach akcji Archeologicznego Zdjęcia Polski, wyniki badań wykopaliskowych $\mathrm{z}$ terenu centralnej Polski, jak i archeologiczne opracowania o charakterze syntetycznym, zredagowane przez Jażdżewskiego (1975).

W praktyce trudno precyzyjnie odróżnić wpływ czynników antropogenicznych i naturalnych, zaznaczających się w rozwoju den dolin rzecznych i ich stoków. Uwzględniono zatem także najnowszą pracę wielu autorów (Starkel i in. 2013), w której m.in. określono fluktuacje klimatu holocenu i przedyskutowano zmiany częstości powodzi w neoholocenie. Ze względu na szczupłość miejsca niniejsza analiza dotyczy jedynie części pradziejów - obejmuje młodszą fazę subboreału (SB-2), najstarszą fazę subatlantyku (SA-1) i kończy się w środkowej części subatlantyckiej fazy SA-2. W pracy wykorzystano równolegle chronologię archeologiczną, albowiem pozwala ona precyzyjniej niż podział chronostratygraficzny holocenu lokować w czasie niektóre zdarzenia. Biorąc pod uwagę chronologię archeologiczną, analiza obejmuje młodszą część pradziejów, poczynając od przełomu I i II okresu epoki brązu, a na przełomie II i III okresu wczesnego średniowiecza kończąc.

\section{Główne cechy rzeźby i budowy geologicznej małych dolin rzecznych środkowej Polski}

W środkowej Polsce przeważają małe doliny rzeczne, co wiąże się z jej położeniem w strefie głównego wododziału Wisły/Odry (ryc. 1). Sieć rzeczna jest najrzadsza na Wzniesieniach Łódzkich i Wysoczyznach Rawskiej oraz Piotrkowskiej (Maksymiuk 1992), ponieważ przez te mezoregiony przebiega wspomniany wododział, a także wododział Bzury/Pilicy. Gęstość sieci rzecznej wzrasta wraz z przesuwaniem się ku peryferyjnym częściom regionu łódzkiego, które odwadniane są przez większe już rzeki, takie jak Warta, Ner, Bzura, Pilica czy Widawka. Małe, podłódzkie doliny rzeczne cechują się długościami od zazwyczaj kilkunastu do kilkudziesięciu kilometrów i powierzchniami zlewni rzędu od kilkudziesięciu do kilkuset kilometrów kwadratowych. Doliny te mają wąskie dna o szerokości 100-300 m i przeważnie niewielką głębokość rzędu 20-30 m, niemniej ich głębokości zwiększają się do 50-60 m w strefie północnej krawędzi Wzniesień Łódzkich. Żywa rzeźba tej części regionu łódzkiego sprzyja dużej wyrazistości morfologicznej małych dolin rzecznych (Turkowska 1988), co mogło przekładać się na silną koncentrację fal osadniczych, wkraczających głównie od północy (z terenów Pradoliny Warszawsko-Berlińskiej) i od zachodu (od strony doliny Warty, głównie poprzez system Neru) w wąskie, podłódzkie doliny rzeczne. W morfologii dolin wyraźnie zaznacza się wysoki, plenivistuliański poziom dolinny (ryc. 2, sygnatura 2), występujący na wysokości do 8-10 m ponad lustro wody w korycie rzecznym. Podkreślenia wymaga miejscami znaczna rozległość tego poziomu (do kilkuset metrów), jego względna równinność oraz charakterystyczna litologia. Zdecydowana przewaga materiału piaszczystego i mułkowego w budowie tego poziomu w połączeniu z monotonią jego rzeźby powodowały, że stanowił on w pradziejach miejsce preferowane do zasiedlenia i gospodarczej eksploatacji środowiska. Do wysokiego poziomu dolinnego nawiązuje gęsta sieć suchych dolin i niecek denudacyjnych (ryc. 2, sygnatura 6), stanowiących relikt peryglacjalnego (vistuliańskiego) systemu dolinnego (Klatkowa 1965). Są to formy o łagodnie nachylonych stokach, także ich dna wykazują niewielkie spadki, a litologia osadów wypełniających niecki i doliny denudacyjne jest $\mathrm{w}$ generalnych zarysach podobna do utworów budujących wysoki poziom dolinny. Dominują tu piaski i mułki, które zazwyczaj są rozdzielone horyzontami kamienistymi. Doliny denudacyjne są formami łączącymi środowiska wysoczyznowe ze środowiskami den dolin rzecznych - rozpoczynają się na wysoczyznach, następnie rozcinają niejednokrotnie strome stoki (ryc. 2, sygnatury 4 i 5) i uchodzą na wysoki poziom dolinny lub dno doliny rzecznej. 


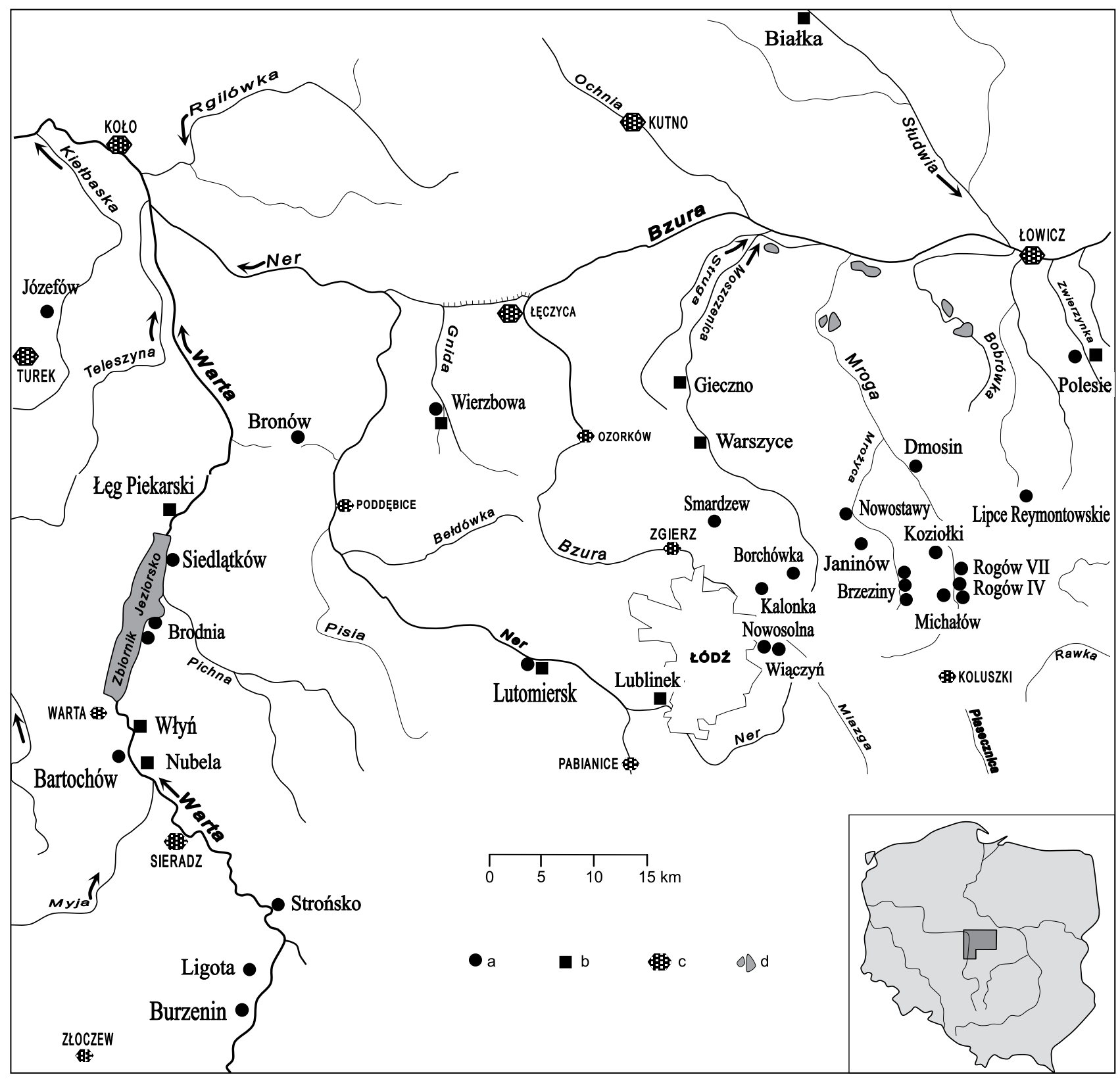

Ryc. 1. Stanowiska z osadami stokowymi (a) i osadami rzecznymi (b) w środkowej Polsce na tle sieci rzecznej Objaśnienia: c - większe miasta, $\mathrm{d}$ - stawy

Fig. 1. Sites with slope deposits (a) and fluvial deposits (b) in Central Poland against the river network Explanations: $\mathrm{c}$ - bigger cities, $\mathrm{d}$ - ponds

\section{Rozmieszczenie osadnictwa pradziejowego w środkowej Polsce}

Osadnictwo pradziejowe środkowej Polski skupiało się przede wszystkim w strefach górnych krawędzi dolin rzecznych i ich stoków. Wzdłuż tych krawędzi tworzyły się charakterystyczne, ułożone równolegle do osi doliny, linijnie wydłużone strefy zagęszczenia punktów osadniczych (ryc. 3). Pośród nich występują zarówno jednofazowe osady ludzkie, jak i stanowiska wielokulturowe. Gęstość osad, które chronologicznie wiąże się z neolitem, była jeszcze stosunkowo niewielka (Wiklak 1975, Papińska 2002). Rozwój osadnictwa następował w starszej części epoki brą- zu (kultury tzw. trzcinieckiego kręgu kulturowego - por. Gąsior 1975, Górski i in. 2011), następnie w jej środkowej i młodszej części (kultura łużycka - por. Kaszewski 1975) i epoce żelaza. W środkowej Polsce zaznaczył się wówczas stopniowy schyłek osadnictwa łużyckiego, w okresie lateńskim (przedrzymskim) epoki żelaza miał miejsce krótkotrwały pobyt ludności kultury pomorskiej/kultury grobów kloszowych (Jadczykowa 1975, Malinowski 1989), a następnie - w okresie wpływów rzymskich - intensywny rozwój osadnictwa kultury przeworskiej (Kaszewska 1975, Godłowski 1985). Wymienione społeczności pradziejowe czerpały liczne korzyści z położenia osad w strefie krawędzi dolin względnie na ich stokach: 


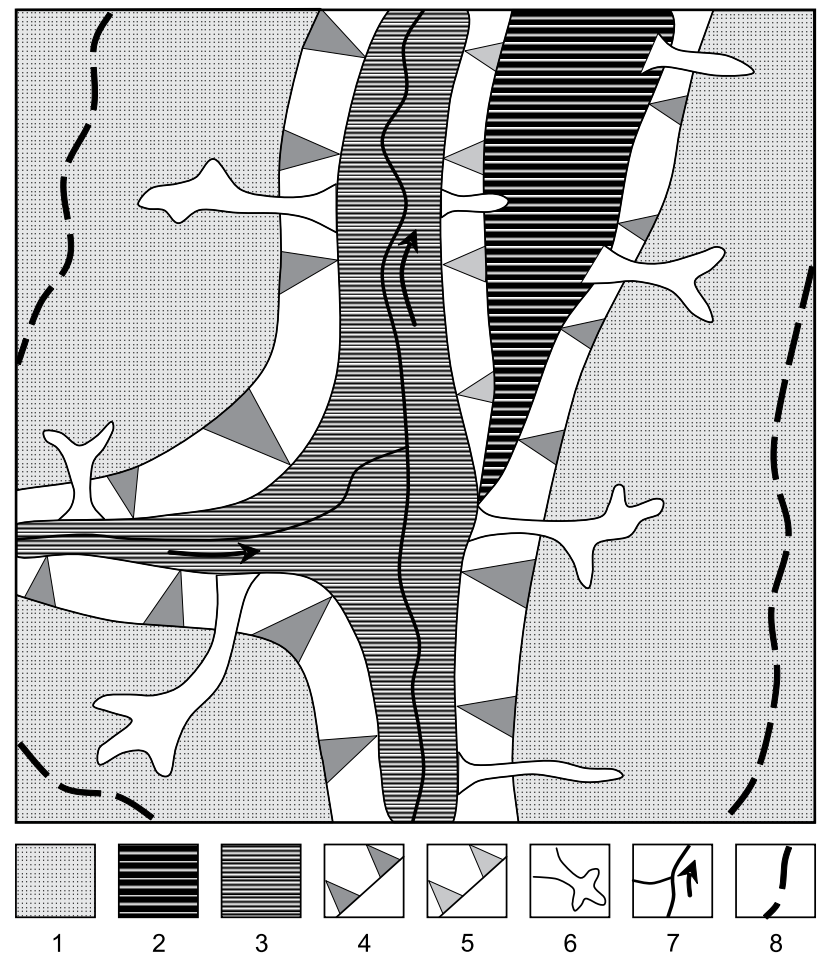

Ryc. 2. Główne elementy rzeźby małych dolin rzecznych w regionie łódzkim (schemat)

1 - wysoczyzny polodowcowe, 2 - wysoki poziom dolinny, 3 - dno doliny głównej i pobocznej, 4 - najstarsze stoki dolin (denudacyjne), 5 - holoceńskie stoki dolin, 6 - niecki i doliny denudacyjne, 7 - koryta rzeczne i kierunki odpływu, 8 - wododziały

Fig. 2. Major landforms of the small river valleys in the Łódź region (a scheme)

1 - glacial plains, 2 - higher valley level, 3 - floors of main and tributary valleys, 4 - oldest valley slopes (denudational), 5 - Holocene valley slopes, 6 - denudational valleys, 7 - river channels and outflow direction, 8 - watersheds

- położenie w pobliżu sieci wód płynących, zatem baza wodna dla osadnictwa była dostępna w zasięgu kilkuminutowego marszu;

- położenie na krawędzi doliny/krawędzi wysokiego poziomu dolinnego całkowicie zabezpieczało przed skutkami wezbrań i powodzi na pobliskiej rzece;

- położenie osady na krawędzi doliny implikowało łatwy dostęp do różnorodnych siedlisk - zarówno bogatożywnych, hydrogenicznych siedlisk dna dolinnego, jak i zróżnicowanych pod względem wydajności i warunków higrycznych siedlisk wysoczyznowych;

- położenie na górnej krawędzi formy wklęsłej niwelowało potencjalnie niekorzystny wpływ procesów morfogentycznych na funkcjonowanie osady i bytowanie jej mieszkańców; wody spłukiwania ulegają tam dekoncentracji, teren szybko i łatwo wysycha po opadach i roztopach - w strefach krawędzi zwierciadło wód gruntowych układało się najczęściej głębiej pod powierzchnią terenu, co zapewniało lepsze warunki do zamieszkiwania różnorodnych obiektów mieszkalnych o niejednokrotnie wziemnych konstrukcjach, a także do przechowywania zasobów;

- położenie w strefie wyższych krawędzi terenowych dawało dobre pole widzenia na otaczający teren, co

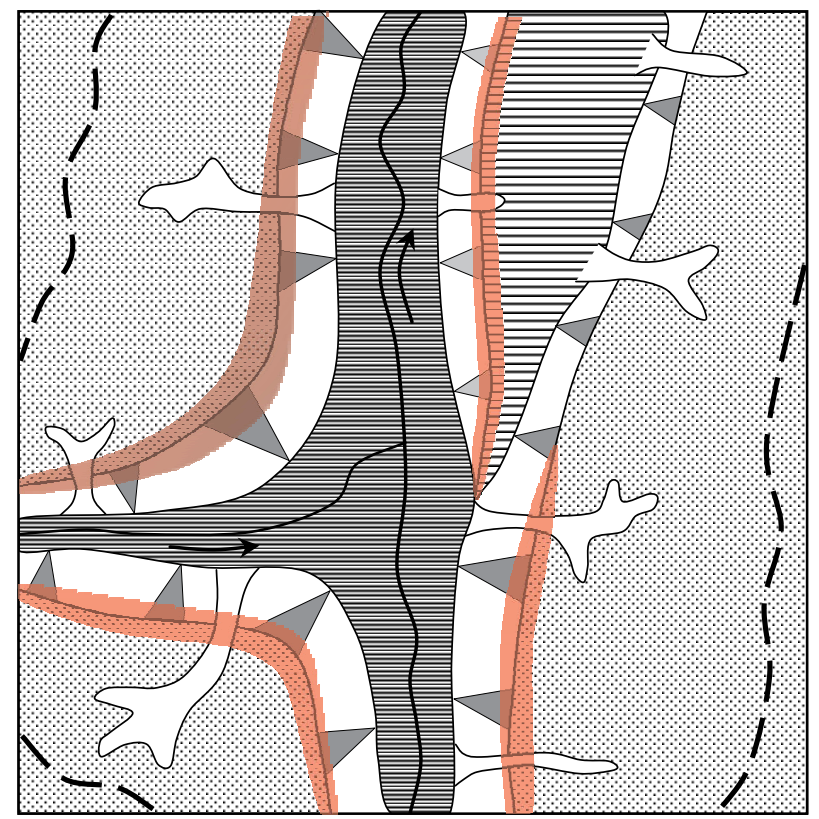

Ryc. 3. Strefy preferowane przez społeczności pradziejowe (czerwony) na tle schematycznego szkicu geomorfologicznego małej doliny rzecznej. Oznaczenia jak na rycinie 2

Fig. 3. Zones preferred by prehistoric communities (in red) against the simplified geomorphic sketch of a small river valley. Explanation as in Figure 2

mogło mieć znaczenie w przypadku pradziejowej gospodarki hodowlanej (np. czuwanie nad bezpieczeństwem stad), a także myślistwa (obserwacja ruchu zwierząt dzikich);

- w strefach krawędzi występują lepsze warunki anemologiczne, co ułatwia rozpalanie ognisk i podtrzymywanie palenisk. Mogło to mieć znaczenie w przypadku osad produkcyjnych lub produkcyjnych części osad pradziejowych.

Jeżeli w dolinie rzecznej występował dobrze rozwinięty, szeroki wysoki poziom dolinny, to sytuacja taka modyfikowała rozmieszczenie osadnictwa. Osady skupiały się wówczas na jego krawędzi (ryc. 3), często znacznie wyeksponowanej przez strome stoki wciosowych dolin holoceńskich (ryc. 2, sygnatura 5). W przypadku rozszerzeń wysokiego poziomu dolinnego do kilkuset metrów górna krawędź doliny rzecznej okazywała się zbyt odległa od miejsc zaopatrzenia w wodę i w związku z tym cechowała się mniejszą już atrakcyjnością dla przedstawicieli kultur pradziejowych (por. górna prawa część ryc. 3).

Szczególnie wyraźne nagromadzenie osad pradziejowych występuje w strefach węzłów hydrograficznych (Kurnatowski 1966), a także w miejscach, gdzie do dolin rzecznych uchodzą większe suche doliny denudacyjne. Gęstość tych form może być znaczna (do ok. $1 \mathrm{~km} \cdot \mathrm{km}^{-2}$ ), a ich cechy morfologiczne i litologiczne powodowały, że były chętnie i efektywnie wykorzystywane do kolonizacji wysoczyzn przylegających bezpośrednio do dolin rzecznych. Dzięki na ogół łagodnemu zarysowi dolin denudacyjnych zmniejszeniu ulegały trudności, jakie mógł napotykać transport czy przeganianie stad zwierząt hodowlanych pomiędzy wysoczyznami a dnem doliny 


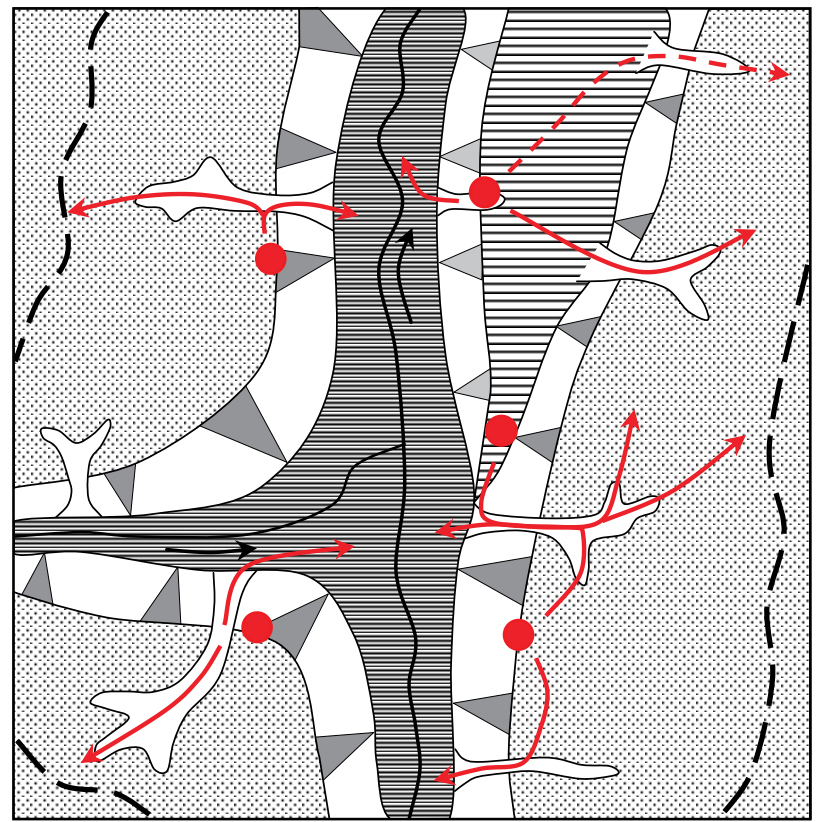

Ryc. 4. Typowe rozmieszczenie osad pradziejowych (czerwone koła) i główne kierunki transportu/przegonu stad pomiędzy wysoczyznami a dnem doliny rzecznej

Fig. 4. Typical distribution of prehistoric settlements (red dots) and main pathways of herds between plains and river valley floors

rzecznej (ryc. 4). Dowodem wykorzystywania suchych dolin denudacyjnych do transportu jest subfosylne rozcięcie drogowe w Rogowie (ryc. 5), obecnie bardzo słabo zaznaczające się w rzeźbie terenu. Nieistniejącą współcześnie drogę polną poprowadzono skośnie przez stok niewielkiego parowu rozcinającego dolinę denudacyjną; szczegółowy opis badanej formy, jej ewolucji i budowy geologicznej zawiera wcześniejsza praca autora (Twardy 2000).

Pewną rolę w eksploatacji środowisk suchych dolin denudacyjnych mógł odgrywać także czynnik litologiczny - stoki niecek i dolin denudacyjnych oraz ich dna są zbudowane $\mathrm{z}$ drobnoziarnistych deluwiów, przeselekcjo-

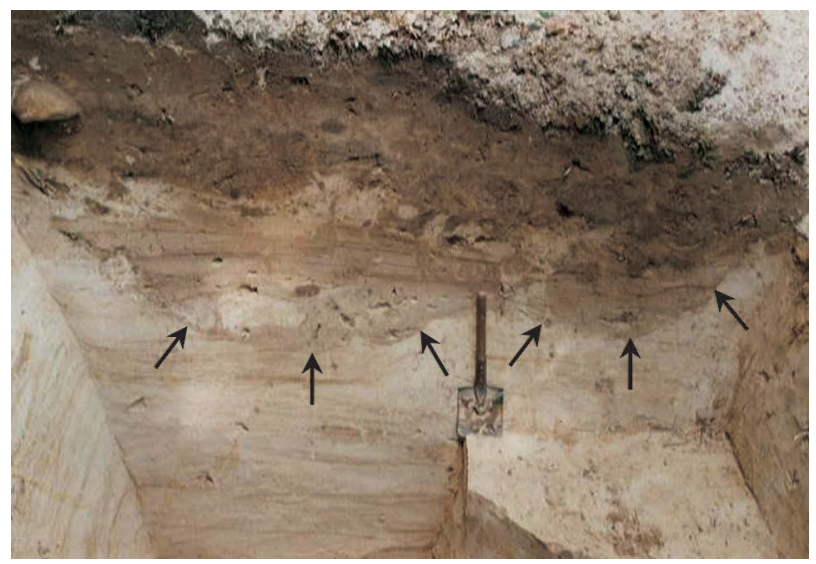

Ryc. 5. Stanowisko Rogów VI. Budowa wypełnienia subfosylnego rozcięcia drogowego. Strzałki pokazują zarysy dwóch symetrycznych kolein na dnie rozcięcia drogowego

Fig. 5. Site Rogów VI. Infilling of the subfossil holweg. Arrows indicate outlines of two symmetrical ruts at the holweg bottom nowanych przez spłukiwanie. Mniejsza szkieletowość występujących w dolinach denudacyjnych gleb deluwialnych mogła być ułatwieniem dla pradziejowej agrotechniki, realizowanej za pomocą niezbyt wytrzymałych narzędzi rolniczych, których budowa opierała się przez długi czas na konstrukcji drewnianej. Generalnie łagodniejsza rzeźba dolin denudacyjnych powoduje zniwelowanie technicznej bariery dla rolnictwa, polegającej na utrudnieniach w uprawie stoków o nachyleniach większych niż kilka stopni.

\section{Konsekwencje pradziejowej kolonizacji dolin rzecznych dla rozwoju ich rzeźby}

Preferowanie do zasiedlenia stref krawędzi dolin rzecznych i/lub krawędzi wysokiego poziomu dolinnego oraz dolin denudacyjnych dawało społecznościom pradziejowym określone korzyści. Zauważyć należy, że zasiedlano i gospodarczo eksploatowano silnie wyeksponowane elementy rzeźby, narażone na działalność procesów stokowych już od momentu ogołocenia ich z roślinności naturalnej (Twardy 2004, Twardy i in. 2004a). Wkroczenie $\mathrm{z}$ trzebieżą lasu w doliny denudacyjne i przygotowywanie tam pól pod uprawę wywoływało również natychmiastowy rozwój procesów stokowych. Liczne argumenty na poparcie wyżej zarysowanych tez można odnaleźć w analizach litologicznych i oznaczeniach wieku pokryw stokowych, stożków deluwialnych i proluwialnych oraz analizach wypełnień dolin denudacyjnych i parowów (Sinkiewicz 1989, 1995, Śnieszko 1995, Smolska 2005, Starkel 2005, Twardy 2008, 2012, Superson i in. 2012 oraz inni). Odnosząc tego rodzaju dane do wiedzy o neoholoceńskim rozwoju den dolin rzecznych, można łatwo zauważyć synchroniczność zdarzeń kształtujących stoki i dna dolinne (ryc. 6). Powyższa rycina ilustruje czasowy związek pomiędzy fazami rozwoju stoków (część C, sygnatura 2) a wynikami wybranych z literatury (Kamiński 1993, 1998, Marosik 2002, Twardy i in. 2004b, Forysiak 2005) datowań rzecznych osadów powodziowych (sygnatura 3). Zdaniem autora dowodzi to ewidentnego i istotnego udziału procesów stokowych w kształtowaniu den małych dolin rzecznych.

Pierwsze świadectwa neoholoceńskiego wzrostu aktywności środowiska rzecznego odnotowano na terenie centralnej Polski w dużej dolinie rzecznej (dolina Warty, por. Forysiak 2005) i określono na 3800-3200 lat BP. W małych dolinach centralnej Polski procesy rzeczne ożywiły się około 3600-3500 lat BP. W generalnych zarysach przytoczone wyżej dane korespondują z początkiem fazy częstszych powodzi, lokowanej przez Starkla i innych (2013) na 3800 lat BP. Składane wówczas w regionie łódzkim osady powodziowe znajdują się w spągu pokrywy madowej o kilkudziesięciocentymetrowej miąższości (stanowisko Ldzań w dolinie Grabi - 3500 lat BP - por. Kamiński, Miklas 1998). Zachodziło także przerywanie akumulacji biogenicznej w paleomeandrach przez liczne 
wkładki materiału mineralnego (stanowisko Łęg Piekarski $-3460 \pm 50$ lat BP - por. Forysiak 2005). Ze stoków uzyskano dowody synchronicznej działalności słabego spłukiwania, zapisane w cienkich warstwach deluwiów, które wydatowano na 3500 lat BP (Wieczorkowska 1997) i $3490 \pm$ lat BP (stanowisko Wierzbowa - Kittel, Twardy 2003). Zdarzenia na stokach i w dolinach rzecznych określono jako I fazę transformacji rzeźby terenu (ryc. 6, sygnatura 1) i powiązano je z działalnością przedstawicieli kultury trzcinieckiej.

Fazę II (3190-2940 lat BP) i III (2730-2380 lat BP) powiązano $\mathrm{z}$ działalnością społeczności kultury łużyckiej w centralnej Polsce. Na stokach stwierdzono w kilku miejscach (stanowiska Lutomiersk, Burzenin, Rogów VII) dalszy przyrost deluwiów uruchamianych przez spłukiwanie, a także akumulację koluwiów (stanowisko Strońsko) i pierwszych diamiktonów rolnych (stanowisko Bronów). Świadczy to o powiększeniu się wachlarza procesów kształtujących stoki i wzroście ich dynamiki. Było to konsekwencją obszerniejszych już wylesień stoków, jak również fluktuacji klimatu w początkach subatlantyku (krótkotrwałe, następujące bezpośrednio po sobie fazy suche i wilgotne - por. Starkel i in. 2013). Wiarygodnie udokumentowanych świadectw intensywniejszej pracy rzek centralnej Polski z przełomu subboreału i subatlantycku niemalże brak z pracy Marosika (2002) wiadomo jedynie, że 3020 \pm 50 lat BP rozpoczęło się narastanie serii powodziowych w małej dolinie Krasówki (Kotlina Szczercowska).

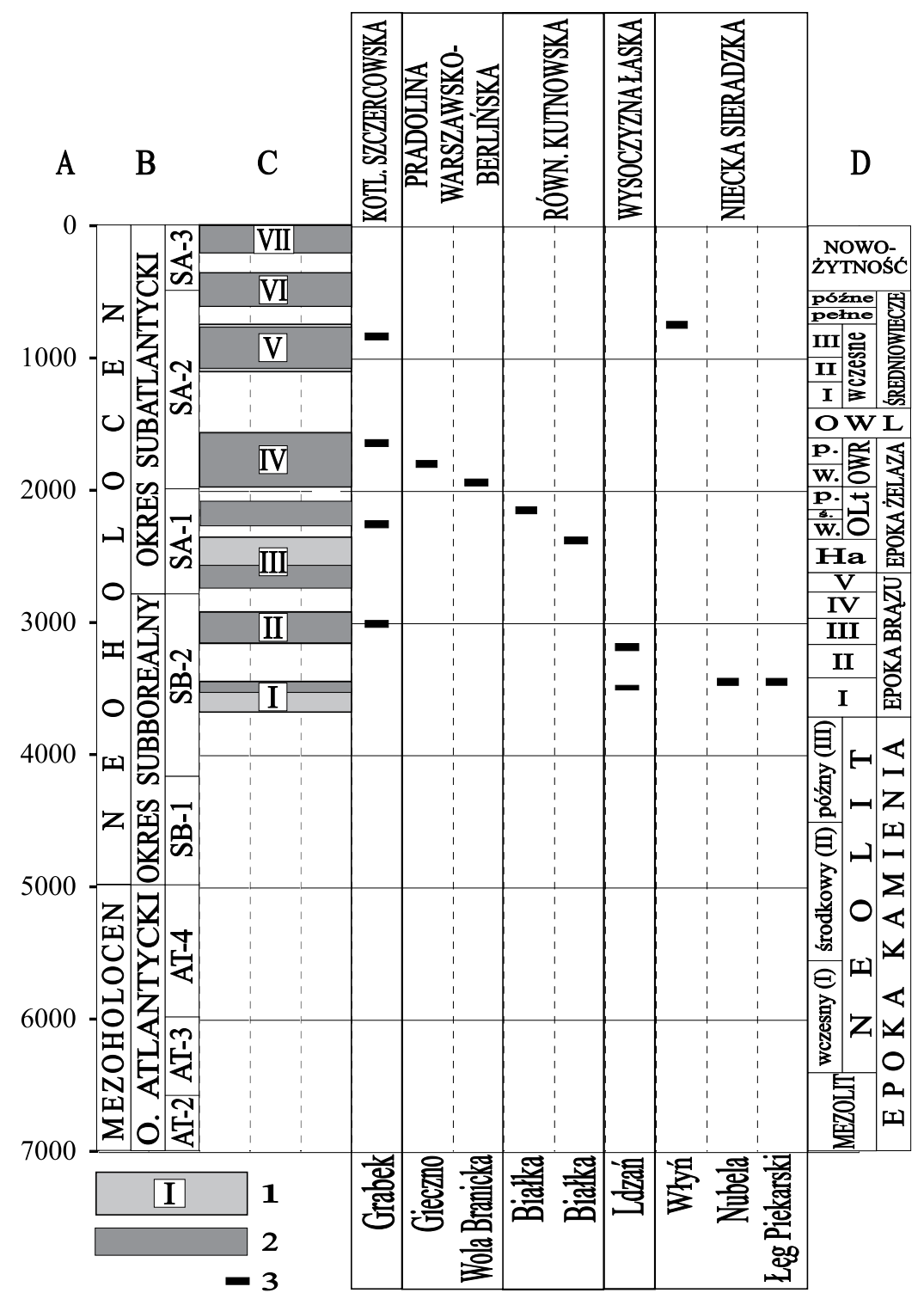

Ryc. 6. Fazy przyspieszonych przeobrażeń rzeźby na tle datowań rzecznych osadów powodziowych w regionie łódzkim w neoholocenie A - lata BP (conv.), B - chronostratygrafia holocenu (wg Starkla 1999), C - fazy przeobrażeń rzeźby eolicznej i stoków, D - chronologia archeologiczna; 1 - główne fazy transformacji rzeźby wraz z numeracją, 2 - etapy przeobrażeń stoków, 3 - wyniki datowań ${ }^{14} \mathrm{C}$ (conv.) rzecznych osadów powodziowych (za Kamińskim 1993, 1998, Kamińskim, Miklasem 1998, Marosikiem 2002, Twardym i in. 2004b, Forysiakiem 2005)

Fig. 6. Phases of accelerated relief transformation against dating of overbank deposits in the Łódź region in the Neoholocene A - BP years (conv.), B - Holocene chronostratigraphy (after Starkel 1999), C - phases of transformation of aeolian relief and slopes, D - archaeological chronology; 1 - main phases of relief transformation with numbers, 2 - stages of slope transformation, 3 - results of ${ }^{14} \mathrm{C}$ dating (conv.) of overbank deposits (after Kamiński 1993, 1998, Kamiński \& Miklas 1998, Marosik 2002, Twardy et al. 2004b, Forysiak 2005) 
Pomiędzy fazami III i IV nastąpił krótkotrwały epizod transformacji rzeźby, który można odnieść do działalności w środowisku centralnej Polski społeczności kultury pomorskiej lub kultury grobów kloszowych. Akumulowane były deluwia (datowane na $2200 \pm 100$ lat BP - por. Kittel 2012) i diamiktony rolne, w których to osadach natrafiono na bezpośrednie dowody uprawy ziemi (Twardy 2009), zapisane $\mathrm{w}$ postaci redlin zachowanych pośród struktur sedymentacyjnych. Zaznaczyło się wówczas odsunięcie stref eksploatowanych gospodarczo w stronę wysoczyzn; wspomniane świadectwa akumulacji osadów stokowych uzyskano ze środkowych lub górnych odcinków suchych dolin denudacyjnych (stanowiska Nowostawy, Brzeziny, Ligota), nawiązujących do dolin rzecznych. W małych dolinach rzecznych narastały nadal osady powodziowe, co stwierdzono w dolinie Krasówki (Marosik 2002) i dolinie Ochni (Twardy i in. 2004b).

Najistotniejsza $\mathrm{z}$ pradziejowych faz transformacji rzeźby terenu (faza IV), datowana na 1970-1490 lat BP, była najbardziej długotrwała. Odnotowano akumulację wszystkich kategorii osadów stokowych: deluwiów (stanowiska Kalonka i Brzeziny), koluwiów (stanowisko Borchówka), diamiktonów rolnych (stanowisko Ligota) oraz proluwiów (stanowisko Lipce Reymontowskie, $1830 \pm 60$ lat BP). Budowa pokryw stokowych stała się bardziej zróżnicowana i złożona, a osady stokowe bardziej gruboziarniste. Szczególnego podkreślenia wymaga akumulacja proluwiów, albowiem dokumentuje ona inicjację erozji wąwozowej na Wzniesieniach Łódzkich. Uruchomienie znaczniejszych ilości materiału mineralnego przez inicjalną erozję wąwozową i bruzdową było skutkiem wylesień, które obejmowały tereny stopniowo coraz bardziej odległe od osi dolin rzecznych, lokalnie sięgające zapewne stref wododziałowych. Przenoszenie się $\mathrm{z}$ gospodarczą eksploatacją środowiska w strefy bardziej oddalone od dolin rzecznych mogło być efektem wzrostu gęstości osad w małych i wąskich dolinach rzecznych. Wówczas zarys strefy eksploatowanej gospodarczo nie mógłby kształtem przypominać koła (ryc. 7), albowiem łatwo dochodziłoby do konfliktu o dostęp do wilgotniejszych siedlisk na dnach dolinnych. Z pracy Sicińskiego (2011) wynika, że wilgotne siedliska den dolin rzecznych miały istotne znaczenie w ekonomice osad chronologicznie wiązanych z okresem wpływów rzymskich, były miejscami zarówno uprawy roślin, jak i hodowli zwierząt. Można przypuszczać, że strefy eksploatowane gospodarczo układały się poprzecznie lub ukośnie w stosunku do osi dolin rzecznych i kształtem przypominały raczej elipsy (ryc. 8). Przesłanki do przyjęcia tej hipotezy daje właśnie rozwój wąwozów - form, których obszary alimentacyjne (zasilania) są położone w górnych częściach stoków dolin rzecznych, górnych odcinkach dolin denudacyjnych i przydolinnych partiach wysoczyzn. Warunkiem koniecznym dla intensywnego rozwoju wąwozów w regionie łódzkim było wylesienie zlewni tych form, ponieważ tylko wtedy występowały epizodyczne, skoncentrowane spływy powierzchniowe, które kształtują tego rodzaju formy erozyjne. Najstarsze podłódzkie wąwozy wcinały się w peryglacjalne doliny denudacyjne, co można odczytywać jako odpreparowanie rzeźby uprzedniej (peryglacjalnej) w warunkach klimatu umiarkowanego i środowiska zmienianego w drastyczny sposób przez środkowopolskie grupy ludności kultury przeworskiej. Kultura ta cechowała się znaczną dynamiką przyrostu liczby ludności (Kurnatowski 1992), a także rozwojem na szeroką skalę metalurgii żelaza, opartej w centralnej Polsce na lokalnych złożach rud darniowych (Woyda 2002).

Podłódzkie wąwozy są obecnie formami stabilnymi, które osiągnęły stadium parowu (Twardy 1995, 2005). Największe $\mathrm{z}$ nich cechują się objętościami rzędu 80 000-100 $000 \mathrm{~m}^{3}$, łącznymi długościami ramion do $4 \mathrm{~km}$, a gęstość rozcięć ich zlewni osiąga $4,62 \mathrm{~km} \cdot \mathrm{km}^{-2}$. Wobec swoich stosunkowo znacznych rozmiarów (jak na warunki Niżu Polskiego) mają nieproporcjonalnie małe stożki akumulacyjne, złożone na dnach dolin rzecznych lub włożone w starsze od wąwozów doliny denudacyjne. Jest wobec tego jasne, że większość (do nawet 90\%) ze zerodowanych w wąwozach osadów weszła w skład pokrywy osadów powodziowych, albowiem lokalne bazy erozyjne wąwozów znajdowały się zawsze na dnach dolin rzecznych. Przeprowadzono oszacowanie stosunku objętości materiału zerodowanego w wąwozach do objętości utworów powodziowych, zakumulowanych na dnach małych, podłódzkich dolin rzecznych. Wynika $\mathrm{z}$ niego, że osady zerodowane z jedynie dwóch wąwozów (stanowiska Brzeziny i Janinów, por. ryc. 1) mogły utworzyć warstwę miąższości $6 \mathrm{~cm}$

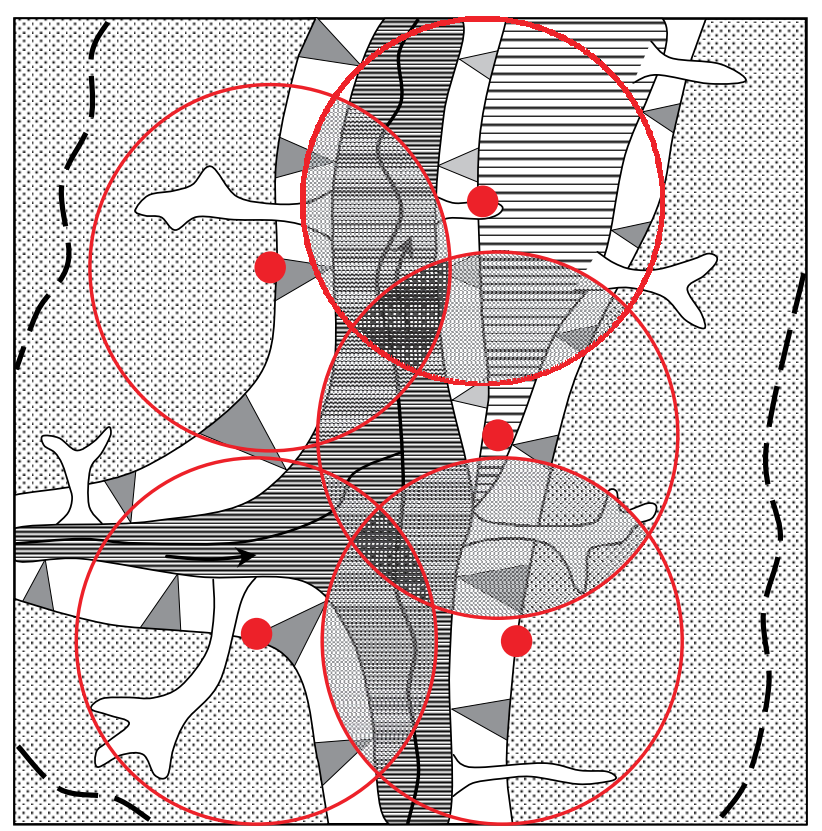

Ryc. 7. Typowe rozmieszczenie osad pradziejowych (koła) z ekwidystantami (okręgi) wyznaczającymi strefy eksploatowane gospodarczo. Wspólne części ekwidystant (zaznaczone na czerwono) obrazują strefy potencjalnego konfliktu o dostęp do den dolin rzecznych

Fig. 7. Typical distribution of prehistoric settlements (red dots) with equidistants indicating sites exploitation territories. Common parts of equidistants (in red) mark the areas of potential conflict of access to river valley floors 


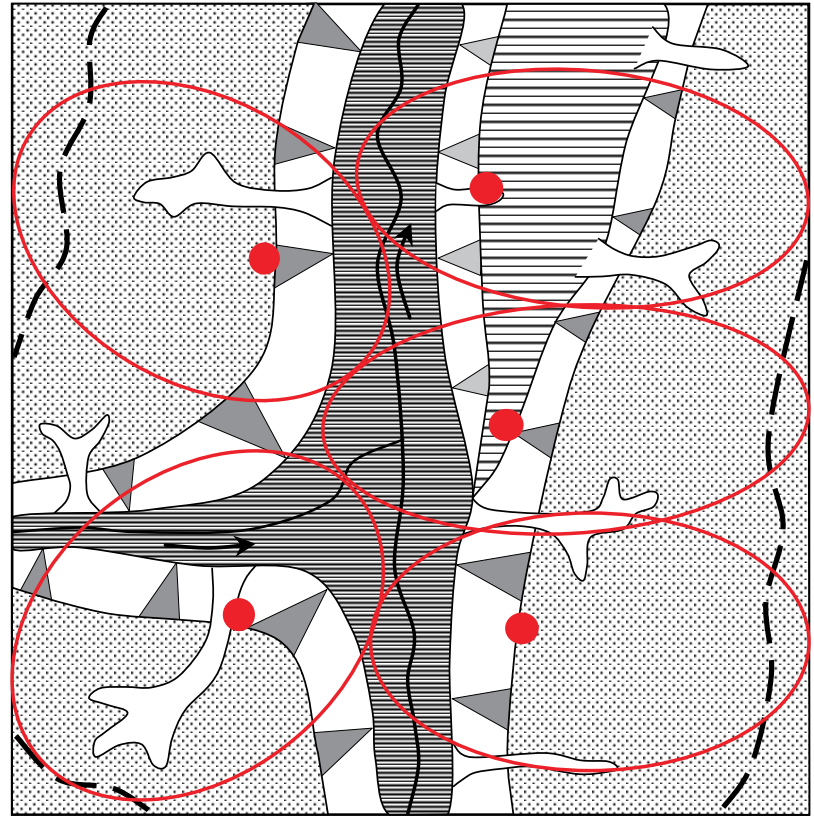

Ryc. 8. Typowe rozmieszczenie osad pradziejowych (koła) z zarysem stref eksploatowanych gospodarczo (elipsy)

Fig. 8. Typical distribution of prehistoric settlements (red dots) with the outline of sites exploitation territories (ellipses)

na dnie doliny Mrożycy, do której nawiązują obie formy (Kamiński, Twardy 1998). W przypadku wąwozów w Lipcach Reymontowskich miąższość warstwy zdeponowanej na dnie doliny Bobrówki wynosiłaby około $10 \mathrm{~cm}$. Wobec około $0,5 \mathrm{~m}$ miąższości pokrywy madowej są to wielkości znaczne. Przytoczone dane świadczą o istotnym udziale procesów stokowych w kształtowaniu den małych dolin rzecznych w neoholocenie.

Z materiałów zestawionych przez M. Krąpca (Starkel i in. 2013) wynika, że pod koniec fazy SA-1 subatlantyku rosła częstość powodzi. Pierwsze, podrzędne maksimum częstych powodzi przypada na okres wpływów rzymskich epoki żelaza (1900-1700 lat BP). Z regionu łódzkiego pochodzą świadectwa szybkiego narastania pokryw osadów powodziowych, datowanych na $1930 \pm 100$ (węgle drzewne z mielerza pogrzebanego przez powódź), $1900 \pm 110$ i $1800 \pm 80$ lat PB (narastanie mad - Kamiński 1993). W dolinie Moszczenicy udokumentowano też świadectwa zatapiania nadrzecznych osad ludności kultury przeworskiej oraz awulsje koryt rzecznych (Kamiński, Moszczyński 1996). Koniec rozwoju pokrywy osadów pozakorytowych wyznacza wynik datowania $1640 \pm 50$ lat BP z doliny Krasówki w Kotlinie Szczercowskiej (Marosik 2002), co zbiega się ze zmniejszeniem częstości powodzi w okresie 1700-1500 lat BP (Starkel i in. 2013). Generalnie w okresie wpływów rzymskich epoki żelaza można zakładać sprzęganie się podsystemu stokowego z systemem małych dolin rzecznych w centralnej Polsce, co wykazano w innej publikacji (Twardy i in. 2004b).

Po okresie wpływów rzymskich w chronologii archeologicznej następuje okres wędrówki ludów, podczas którego tereny środkowej Polski wyludniły się niemal zupełnie (Łaszczewska 1975). Ustał rozwój procesów stokowych, dochodziło do regeneracji gleb (stanowisko
Dmosin - por. Twardy i in. 2008) i szaty roślinnej. Występuje około 400-500-letnia stabilizacja zarówno stoków, jak i den dolinnych (ryc. 6), która zakończyła się dopiero we wczesnym średniowieczu wraz z nadejściem i okrzepnięciem społeczności słowiańskich w centralnej Polsce. Nastąpiło wstrzymanie rozwoju rzeźby pomimo bardzo sprzyjających warunków klimatycznych (skokowy i znaczny wzrost częstości powodzi i wyraźna faza wilgotna w latach 1500-1350 BP - Starkel i in. 2013). Dowodzi to, że osłabienie roli czynników antropogenicznych (regres osadnictwa) w bardzo wyraźny sposób przyczynia się do stabilizacji procesów rzeźbotwórczych, zapisanych w osadach geologicznych i formach rzeźby terenu.

\section{Podsumowanie}

Rozwój rzeźby den małych dolin rzecznych w środkowej Polsce był powiązany i synchroniczny z intensywnym rozwojem stoków. Zaznaczyła się agradacja den dolinnych, zachodząca wskutek narastania pokrywy osadów powodziowych i nakrywania brzeżnych partii dna przez różnego rodzaju stożki akumulacyjne (deluwialne, proluwialne), a także terasy rolne. Najsilniej transformowane były krawędzie dolin rzecznych lub silnie wyeksponowane krawędzie wysokiego poziomu dolinnego podłódzkich rzek, ponieważ w tych strefach skupiało się osadnictwo. Do form rzeźby preferowanych przez społeczności pradziejowe należały też niecki i doliny denudacyjne, licznie występujące na stokach dolin rzecznych. Utworzyły one podstawowe osie transportu materiału $\mathrm{z}$ wysoczyzn na dna dolinne, w dużych dolinach denudacyjnych jeszcze w pradziejach zostały również zapoczątkowane procesy erozji wąwozowej. W młodszej części subboreału i starszej części subatlantyku doszło do przyspieszonej transformacji rzeźby w ciągu czterech stosunkowo krótkich, przeważnie 200-300-letnich faz, które miały kontynuację także w średniowieczu i okresie nowożytnym. Fazy jednoczesnej transformacji stoków i nadbudowy den dolinnych zbiegają się z rozwojem kultur pradziejowych w środkowej Polsce, co wskazuje, że głównym czynnikiem sterującym neoholoceńskim rozwojem rzeźby terenu była antropopresja. Fluktuacje klimatu neoholocenu mogły zwiększać skalę przekształceń rzeźby oraz przyczyniać się do wzrostu dynamiki denudacji antropogenicznej i zmian rzeźby den dolin rzecznych.

\section{Podziękowanie}

Autor składa podziękowanie anonimowemu recenzentowi za wnikliwe uwagi do pierwotnej wersji manuskryptu. 


\section{Literatura}

Domańska L., Kittel P., Forysiak J. (red.), 2009. Środowiskowe uwarunkowania lokalizacji środowiska. Ser. wyd. SAS ,Środowisko-Człowiek-Cywilizacja”. T. II. Bogucki Wyd. Nauk., Poznań.

Forysiak J., 2005. Rozwój doliny Warty między Burzeninem i Dobrowem po zlodowaceniu warty. Acta Geographica Lodziensia 90: $1-116$.

Gąsior M., 1975. Kultura trzciniecka na obszarze Polski środkowej. Prace i Mat. Muz. Archeol. i Etnogr. w Lodzi, ser. Archeol. 22: 101-121.

Godłowski K., 1985. Przemiany kulturowe i osadnicze w południowej i środkowej Polsce w młodszym okresie przedrzymskim i w okresie rzymskim. Prace Kom. Archeolog. 23. Ossolineum, Wrocław-Warszawa.

Górski J., Makarowicz J., Wawrusiewicz A. (red.), 2011. Osady i cmentarzyska społeczności trzcinieckiego kręgu kulturowego w Polesiu, stanowisko 1, woj. łódzkie. T. I. Spatium Archaeologicum. Vol. 2. Instytut Archeologii Uniwersytetu Łódzkiego, Fundacja Uniwersytetu Łódzkiego.

Jadczykowa I., 1975. Kultura wschodniopomorska i kultura grobów kloszowych w Polsce środkowej. Prace i Mat. Muz. Archeol. i Etnogr. w Łodzi, ser. Archeol. 22: 167-194.

Jażdżewski K. (red.), 1975. Studia nad pradziejami Polski środkowej. Prace i Mat. Muz. Archeol. i Etnogr. w Łodzi, ser. Archeol. 22: 1-434.

Kamiński J., 1993. Późnoplejstoceńska i holoceńska transformacja doliny Moszczenicy. Acta Geographica Lodziensia 64: 1-104.

Kamiński J., 1998. Wykształcenie i wiek osadów dolin rzecznych Wyżyny Łódzkiej i Pradoliny Warszawsko-Berlińskiej w świetle osadnictwa pradziejowego. Mat. sympozjum ,Rola człowieka prehistorycznego w przemianach środowiska przyrodniczego". UŚl., Sosnowiec, 2-3.03.1998: 5-6.

Kamiński J., Miklas M., 1998. Stanowisko Ldzań. Vistuliańskie uwarunkowania holoceńskiej działalności eolicznych i fluwialnych procesów morfogenetycznych w dolinie Grabi. Mat. sympozjum „Rola plejstoceńskich procesów peryglacjalnych w modelowaniu rzeźby Polski", Łodź, 7-8.12.1998: 31-32.

Kamiński J., Moszczyński J., 1996. Wpływ osadnictwa kultury przeworskiej na kształtowanie doliny Moszczenicy w okolicy Woli Branickiej. Acta Geographica Lodziensia 71: 56-66.

Kamiński J., Twardy J., 1998. Przemiany krajobrazu w holocenie. W: J.K. Kurowski (red.), Park Krajobrazowy Wzniesień Łódzkich, Wyd. Eko-Wynik, Łódź: 32-38.

Kaszewska E., 1975. Kultura przeworska w Polsce środkowej. Prace i Mat. Muz. Archeol. i Etnogr. w Lodzi, ser. Archeol.,22: 195-254.

Kaszewski Z., 1975. Kultura łużycka w Polsce środkowej. Prace i Mat. Muz. Archeol. i Etnogr. w Łodzi, ser. Archeol. 22: 123-165.

Kittel P., 2012. Budowa i ewolucja doliny Neru w rejonie stanowiska Lutomiersk-Koziówki w świetle badań geoarcheologicznych. Acta Geographica Lodziensia 100: 113-134.

Kittel P., Twardy J., 2003. Wpływ pradziejowej aktywności ludzkiej na funkcjonowanie stoku w Wierzbowej (Pradolina Warszawsko-Berlińska). W: J.M. Waga, K. Kocel (red.), Człowiek w środowisku przyrodniczym - zapis działalności. PTG, O/Katowicki, Sosnowiec: 68-73.

Klatkowa H., 1965. Niecki i doliny denudacyjne w okolicach Łodzi. Acta Geographica Lodziensia 19: 1-142.

Kurnatowski S., 1966. Przemiany techniki uprawy roli w czasach między epoką brązową i wczesnym średniowieczem. Stud. z Dziejów Gosp. Wiejsk. 8: 92-99.

Kurnatowski S., 1992. Próba oceny zaludnienia ziem polskich między XIII w. p.n.e. a IV w. n.e. W: K. Kaczanowski, S. Kurnatowski, A. Malinowski, J. Piontek (red.), Zaludnienie ziem polskich między XIII w. p.n.e. a IV w. n.e. - materiały źródłowe, próba oceny. SGH, Monogr. i Oprac. 342: 15-111.

Łaszczewska T., 1975. Polska środkowa w okresie wędrówek ludów i w początkach wczesnego średniowiecza. Prace i Mat. Muz. Archeol. i Etnogr. w Łodzi, ser. Archeol. 22: 293-330.

Maksymiuk Z., 1992. Zależność między gęstością sieci rzecznej a przepuszczalnością podłoża w środkowej Polsce. Acta Univ. Lodziensia, Folia Geographica 16: 7-17.
Malinowski T., 1989. Ekspansja kultury pomorskiej i charakter tej ekspansji. W: J. Kmieciński (red.), Pradzieje ziem polskich. T. 1-2. PWN, Warszawa-Lódź: 570-573.

Marosik P., 2002. Ukształtowanie terenu i warunki geologiczne na stanowisku archeologicznym nr $11 \mathrm{w}$ Grabku oraz na obszarze przyległym w dnie doliny Krasówki. W: R. Grygiel (red.), Badania archeologiczne na terenie odkrywki „Szczerców” Kopalni Węla Brunatnego „Bełchatów” S.A. T. II. Fund. Bad. Archeolog. im. K. Jażdżewskiego, Fund. UAM, Łódź: 9-23.

Papińska E., 2002. Wpływ antropopresji na przemiany środowiska geograficznego województwa łódzkiego. Acta Geographica Lodziensia.

Siciński W., 2011. Zadowice nad Prosną. Zespół osadniczy kultury przeworskiej z okresu wpływów rzymskich. Fund. Bad. Archeol. im. K.Jażdżewskiego, MAiE w Łodzi, Łódź.

Sinkiewicz M., 1989. Zmiany rzeźby terenu Pojezierza Kujawskiego pod wpływem procesów stokowych. Stud. Soc. Sci. Torun. C, 9(6): 104.

Sinkiewicz M., 1998. Rozwój denudacji antropogenicznej w środkowej części Polski północnej. Wyd. UMK, Toruń.

Smolska E., 2005. Znaczenie spłukiwania w modelowaniu stoków młodoglacjalnych (na przykładzie Pojezierza Suwalskiego). WGiSR UW, Warszawa.

Starkel L., 2005. Anthropogenic soil erosion since the Neolithic in Poland. Z. Geomorph. N. F., Suppl. 139: 189-201.

Starkel L., 2006a. Czy można oddzielić wpływ czynników klimatycznych od antropogenicznych w przekształceniu geosystemów? Seminarium ,Jak oddzielić wpływ zmian klimatycznych od antropogenicznych w młodszym holocenie na obszarze Polski”. PAN, Kraków, 11. 2007: 1-2.

Starkel L., 2006b. Klimat a człowiek w transformacji środowiska przyrodniczego Polski. W: M. Gutry-Korycka, A. Kędziora, L. Starkel, L. Ryszkowski (red.), Długookresowe przemiany krajobrazu Polski w wyniku zmian klimatu i użytkowania ziemi. Poznań: 9-15.

Starkel L., Michczyńska J.D., Krąpiec M., Margielewski W., Nalepka D., Pazdur A., 2013. Progress in the Holocene chrono-climatostratigraphy of Polish territory. Geochronometria 40(1): 1-21, DOI: $10.2478 / \mathrm{s} 13386=012-0024-2$

Superson J. (red.), 2012. Morfogeneza stożków napływowych w dolinie Bystrej (Płaskowyż Nałęczowski, Wyżyna Lubelska). UMCS, Lublin.

Śnieszko Z., 1995. Ewolucja obszarów lessowych wyżyn polskich w czasie ostatnich 15000 lat. Pr. Nauk. U Śl. 1107.

Turkowska K., 1988. Rozwój dolin rzecznych na Wyżynie Łódzkiej w późnym czwartorzędzie. Acta Geographica Lodziensia 57: 1-157.

Twardy J., 1995. Dynamika denudacji w strefie krawędziowej Wyżyny Łódzkiej. Acta Geographica Lodziensia 69: 1-213.

Twardy J., 2000. Deluwia neoholoceńskie - przykłady z Wyżyny Łódzkiej. Acta Geographica Lodziensia 78: 135-173.

Twardy J., 2003. Cechy sedymentologiczne neoholoceńskich osadów stokowych na Wyżynie Łódzkiej i ich wartość interpretacyjna. Prace i Studia Geograficzne WGiSR UW 33: 25-44.

Twardy J., 2004. Przebieg holoceńskiej ewolucji stoków doliny Warty na obszarze południowej części Kotliny Sieradzkiej w świetle analiz osadów stokowych. Acta Geogr. Lodz. 88: 49-84.

Twardy J., 2005. Gully erosion in the Middle Poland. W: J. Rejman, W. Zgłobicki (red.), Human impact on sensitive geosystems. Wyd. UMCS: $129-142$.

Twardy J., 2008. Transformacja rzeźby centralnej części Polski Środkowej w warunkach antropopresji. Wyd. UŁ, Łódź.

Twardy J., 2009. Bezpośredni zapis działalności gospodarczej człowieka w osadach stokowych i eolicznych w centralnej Polsce. Środowisko-Człowiek-Cywilizacja. T. II, Poznań: 323-328.

Twardy J., 2011. Influence of man and climate changes on relief and geological structure transformation in Central Poland since the Neolithic. Geographica Polonica 84: 163-178.

Twardy J., Forysiak J., Kittel P., 2004a. Dynamika procesów morfogenetycznych uruchomionych i zintensyfikowanych wskutek pradziejowej działalności ludzkiej w Pradolinie Warszawsko-Berlińskiej. Acta Geographica Lodziensia 88: 85-118.

Twardy J., Forysiak J., Rzepecki S., 2008. Przeobrażenia rzeźby ostańca wysokiego poziomu dolinnego rzeki Mrogi (Wysoczyzna Łódzka) w warunkach antropopresji w świetle archeologicznych badań wy- 
kopaliskowych i analiz geomorfologicznych. Landform Analysis 9: 328-333.

Twardy J., Kamiński J., Moszczyński J., 2004 b. Zapis gospodarczej i osadniczej działalności człowieka z okresu lateńskiego i rzymskiego w formach i osadach Polski Środkowej. W: D. Abłamowicz, Z. Śnieszko (red.), Zmiany środowiska geograficznego w dobie gospodarki rolno-hodowlanej. Studia z obszaru Polski. Muz. Śląskie

w Katowicach, Stow. Nauk. Archeol. Polsk, O/Katow., Katowice: 197-221.
Waga J.M., Kocel K. (red.), 2003. Człowiek w środowisku przyrodniczym - zapis działalności. PTG, O/Katowicki, Sosnowiec.

Wieczorkowska J., 1997. Przykłady parowów na krawędzi Wyżyny Łódzkiej. Acta Geographica Lodziensia, Folia Geographica Physica 1: 258-261.

Wiklak H., 1975. Neolit w Polsce środkowej. Prace i Mat. Muz. Archeol. i Etnogr. w Łodzi, ser. Archeol. 22: 67-99.

Woyda S., 2002. Źródło żywiołów. Mazowieckie centrum metalurgiczne z czasów Imperium Rzymskiego (I wiek p.n.e.-IV wiek n.e.). Archeol. Żywa 1: 7-13. 